\title{
CHEMICAL PROCESS FOLLOWED BY ACTIVATED SLUDGE TREATMENT OF COTTON PULPING EFFLUENTS FOR NITROCELLULOSE PRODUCTION
}

\author{
L. F. Santos ${ }^{1}$, F.T. Silva ${ }^{2}$, T.C.B. Paiva ${ }^{3}$ \\ ${ }^{1}$ Chemical Engineering Department, Engineering school of Lorena, University of São Paulo, Lorena, Brazil \\ ${ }^{2}$ Biotechnology Department, Engineering school of Lorena, University of São Paulo, Lorena, Brazil \\ ${ }^{3}$ Biotechnology Department, Engineering school of Lorena, University of São Paulo, Lorena, Brazil
}

\begin{abstract}
The present research work aims to characterize cotton pulping effluents (black liquor and washing waters) for producing nitrocellulose to be used in explosives manufacture. After characterization, equal portions of the effluent samples were mixed, thereby forming a homogeneous mixture called as the pulping effluent which was treated by a chemical process followed by the activated sludge biological treatment. The main results of the pulping effluent initial characterization were: $p H$ at 12.4, 28,530 UC color, 7,797 mg/L COD, 4,399 mg/L BOD, 2,455 mg/L TOC, 9,269 mg/L TSS, 4,035mg/L TFS and 5,234mg/L TVS. The chemical treatment consisted in acidifying the pulping effluent with an acid effluent from the stage of cellulose nitration until reaching $\mathrm{pH}=1.5+0.3$, which allowed coagulating/decanting a large amount of the organic materials in the sample. After $\mathrm{pH}$ was adjusted to $7+0.2$, the chemically treated effluent was submitted to the activated sludge treatment in a 500L reactor in a semi-continuous process. The chemical process integration with the activated sludge treatment allowed reducing color by $95.8 \%$, COD by $96.4 \%$, BOD by 99\%, TOC by 97.8\%, TSS by 96.9\%, TFS by $95.8 \%$ and TVS by $97.8 \%$. The obtained results from the scale-up showed that these processes integration was effective at treating the cotton pulping effluents, thus confirming the results obtained on smaller scales.
\end{abstract}

Keywords: Effluent, Treatment, Cotton, Black Liquor

\section{INTRODUCTION}

Environmental pollution is a global concern. However, the environment has been continuously contaminated because many industrial processes are inherently polluting [1-3]. Nitrocellulose production is an example of an industrial process that generates waste which, if not properly treated, largely contributes to increased environmental contamination [2,3]. Effluents from the lignocellulosic industry are also characterized by high toxicity which is caused by chlorophenols, chlorolignins, organic acids, acid resins, dioxins and their derivatives $[4,7]$.

Treatment systems are supposed to remove pollutants from effluents so as to suit their release into the environment, which is associated with the concepts of treatment level and efficiency [8]. There are several treatment methods, such as physical, chemical and biological treatments, or their integration.

In chemical treatments, the removal or conversion of contaminants occurs by adding chemicals or through chemical reactions, e.g. precipitation and oxidation. Chemical precipitation occurs by adding a reagent which is capable of interacting with the material to be removed so as to form a stable precipitate that can be easily removed, thus improving the final effluent quality. Oxidative methods are characterized by transforming organic matter into carbon dioxide, water and inorganic ions by means of degradation reactions involving transient oxidizing species, especially hydroxyl radicals $[9,10]$. Biological treatments are methods in which contaminants are removed through biological activity which is similar to natural processes that occur in a body of water after effluent disposal, from which organic matter is converted into inert minerals by natural mechanisms, i.e. autodepuration. The most common and widely used method is the activated sludge process [10, 13$15]$.

The activated sludge process consists in keeping a diversified active mass of organisms, which is able to stabilize the organic matter in the effluent in the presence of oxygen and initially remove the colloidal and suspended solids by physical agglomeration, flocculation and adsorption within the biological flocs. Afterwards, the organic matter is decomposed by biological oxidation and transformed into $\mathrm{CO}_{2}, \mathrm{H}_{2} \mathrm{O}, \mathrm{NH}_{3}$, new organisms, energy, among other products. The activated sludge process can be integrated with other processes to improve final effluent quality [12-14].

Thus, this work presents the partial results of a research aimed to characterize and treat cotton pulping process effluents for producing nitrocellulose, so that it can be used to manufacture explosives through the integration of a chemical process with the activated sludge process. 


\section{MATERIALS AND METHODS}

\subsection{Pulping Effluent}

The present work has been developed at an industry where the pulping process is carried out in autoclaves (batch) with a solution of sodium hydroxide $(\mathrm{NaOH})$ at $25 \mathrm{~g} / \mathrm{L}$ concentration and $150^{\circ} \mathrm{C}$, and about $6 \mathrm{Kgf} / \mathrm{cm} 2$ pressure for approximately 80 minutes. The delignified cotton was washed several times with water, which generated, at this stage, an effluent which is rich in lignin with a dark color and high biochemical oxygen demand (BOD). The mixture of these effluents was called as pulping effluent.

\subsection{Samples Collection and Characterization}

The samples were collected while they were being disposed of (concentrated effluents and washing waters), whose $\mathrm{pH}$, total suspended solids (TSS), total fixed solids (TFS), total volatile solids (TVS), color, total organic carbon (TOC), chemical oxygen demand (COD), biochemical oxygen demand (BOD), acidity index and free chlorine level have been characterized before and after treatment, according to analytical specific methods developed by the company itself and conventional techniques of effluent analysis [17].

\subsection{Treatment Process}

Pulping Effluent: a chemical treatment process has been integrated with activated sludge so as to treat the pulping effluent. The chemical treatment consisted in acidifying the sample with the effluent from the stage of cellulose nitration until reaching $\mathrm{pH}=1.5+0.3$. Otherwise, it was used a solution of sulfuric acid whose content ranged from $30 \%$ to $50 \%$. It was carried out in 4 PVC containers with $200 \mathrm{~L}$ capacity and a drain valve that was $30 \mathrm{~cm}$ away from their base (Figure 1). $\mathrm{pH}$ was monitored with a $\mathrm{pH}$ meter manufactured by MICRONAL TM, model B-374. Once flocculation and precipitation of a large amount of the organic material in the mixture ( 2 hours) were complete, the supernatant was separated by draining, which was then characterized.

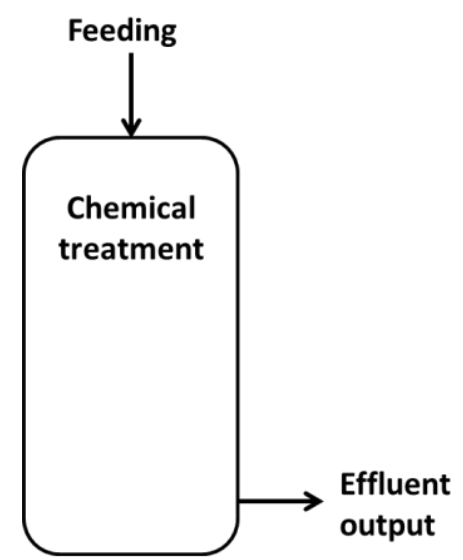

Fig 1 - Chemical treatment reactor / 200L capacity [16]

After adjusting $\mathrm{pH}$ to $7.0+0.2$, the chemically treated effluent was submitted to the activated sludge process. The biological treatment was performed in a stainless steel reactor with $500 \mathrm{~L}$ capacity and three valves (Figure 2). The air was supplied through compressors, whose distribution inside the reactor was performed by diffusers at such an intensity that, in addition to keeping the microbial mass under suspension, provided minimum oxygen concentration at $8 \mathrm{mg} / \mathrm{L}$, with feeding/hibernation cycles of every 6 hours. It took 15 minutes for the sludge sedimentation. The reactor was started with sludge that was kindly provided by Kimberly-Clark Brazil - KCB ${ }^{\mathrm{TM}}$.

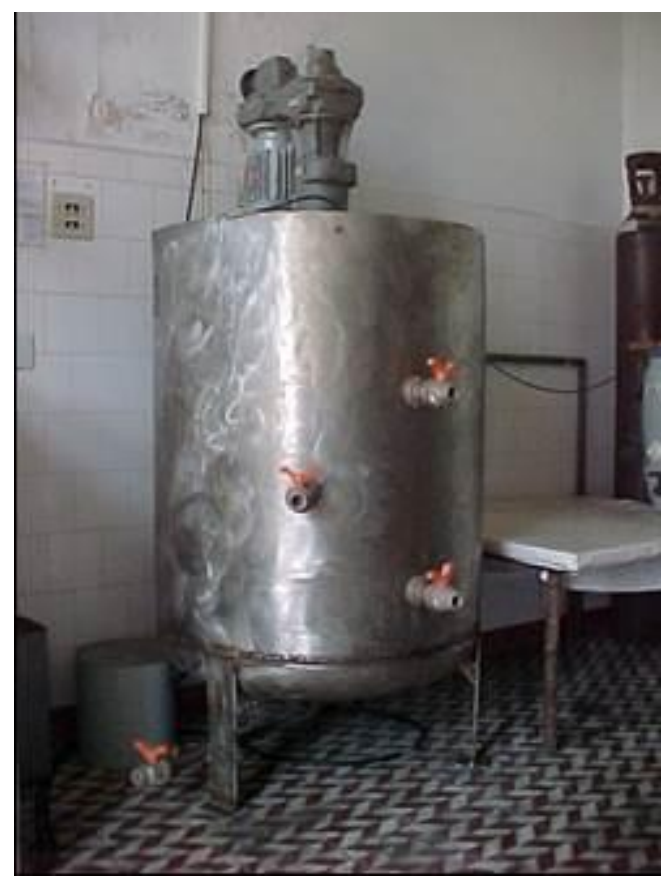

Fig 2- Biological reactor / 500L capacity

\section{RESULTS AND DISCUSSION}

The black liquor presented $\mathrm{pH}$ of 13.7 , i.e. well above the emission standards established by the Brazilian environmental legislation which recommends $\mathrm{pH}$ between 5 and 9 for its disposal [17].This effluent presented 125,515 UC color, a very high value, which can alter the characteristics of the receptor body [4].

The black liquor total solid concentration was $33,508 \mathrm{mg} / \mathrm{L}$, distributed along $14,911 \mathrm{mg} / \mathrm{L}$ of total fixed solids (inorganic compounds) and 18,597mg/L of total volatile solids (organic compounds). The inorganic fraction composition can be attributed mainly to the sodium hydroxide being used in the cotton pulping process and, to a lesser extent, the inorganic compounds present in raw cotton.

The concentration of organic compounds $(18,597 \mathrm{mg} / \mathrm{L})$, which was calculated by the difference between total solids and total fixed solids, leads to high chemical and biochemical oxygen demand, whose values were $29,914 \mathrm{mg} / \mathrm{L}$ and $18,812 \mathrm{mg} / \mathrm{L}$, respectively. The total nitrogen value $(71 \mathrm{mg} / \mathrm{L})$ was higher than that which is recommended by legislation $(20 \mathrm{mg} / \mathrm{L})$. As regards phosphorus, the values were below $5 \mathrm{mg} / \mathrm{L}$, thus showing that its concentration in the black liquor was insignificant. 
As black liquor, the effluent from the first washing also presented dark color (33,864 CU), high $\mathrm{pH}$ levels (13.5), COD $(8.901 \mathrm{mg} / \mathrm{L})$, BOD $(5,586 \mathrm{mg} / \mathrm{L})$, TSS $(11,282 \mathrm{mg} / \mathrm{L}$, TFS $(4,938 \mathrm{mg} / \mathrm{L})$ andTVS $(6,344 \mathrm{mg} / \mathrm{L})$. The other effluents $\left(2^{\text {nd }}, 3^{\text {rd }}, 4^{\text {th }}, 5^{\text {th }}\right.$ and $6^{\text {th }}$ washings $)$, although being diluted, increase the organic load that is released into the existing treatment plant in the industry, thereby raising the BOD values.
During the washing process, there was no marked change in $\mathrm{pH}$ which varied between 11.8 and 13.5. However, the other parameters (color, COD, BOD, SST, TFS, TVS and nitrogen) varied significantly, as it could be observed in Table 1.

Table 1 - Characterization of effluents from the pulping stage of cotton [5]

\begin{tabular}{|c|c|c|c|c|c|c|c|c|}
\hline \multirow{2}{*}{ Parameters } & \multirow{2}{*}{$\begin{array}{l}\text { Black } \\
\text { liquor }\end{array}$} & \multicolumn{6}{|c|}{ Washings } & \multirow{2}{*}{$\begin{array}{l}\text { Pulpingeffluen } \\
\mathrm{t}\end{array}$} \\
\hline & & $1^{-\mathrm{a}}$ & $2^{-\mathrm{a}}$ & $3^{\mathrm{a}}$ & $4^{-\mathrm{a}}$ & $5^{\mathrm{a}}$ & $6^{\mathrm{a}}$ & \\
\hline $\mathrm{pH}$ & 13.7 & 13.5 & 13.3 & 12.9 & 12.8 & 12.6 & 11.8 & 12.4 \\
\hline Color [CU] & 125,515 & 33,864 & 15,114 & 8,068 & 3,258 & 1,122 & 572 & 28,530 \\
\hline $\mathrm{COD}[\mathrm{mg} / \mathrm{L}]$ & 29,914 & 8,901 & 4,661 & 2,099 & 1,044 & 470 & 143 & 7,797 \\
\hline $\mathrm{BOD}[\mathrm{mg} / \mathrm{L}]$ & 18,812 & 5,586 & 2,918 & 1,305 & 641 & 297 & 73 & 4,389 \\
\hline TSS [mg/L] & 33,508 & 11,282 & 6,797 & 4,086 & 2,971 & 2,363 & 2,107 & 9,269 \\
\hline TFS [mg/L] & 14,911 & 4,938 & 2,925 & 1,709 & 1,209 & 936 & 781 & 4,035 \\
\hline TVS [mg/L] & 18,597 & 6,344 & 3,872 & 2,377 & 1,762 & 1,427 & 1,326 & 5,234 \\
\hline Nitrogen [mg/L] & 71 & 32 & 26 & 19 & 17 & 16 & 15 & 27 \\
\hline Phosphorus [mg/L] & $<5$ & $<5$ & $<5$ & $<5$ & $<5$ & $<5$ & $<5$ & $<5$ \\
\hline
\end{tabular}

The organic fraction is responsible for the major problems that arise from such effluents, such as its intense color $(125,515 \mathrm{UC})$, which hinders the penetration of solar rays into water courses, thence damaging the photosynthetic activity of the aquatic flora, resulting in high toxicity and high chemical and biochemical oxygen demands, which are attributed to resins and phenolic compounds derived from lignin $[5,20]$.

Figure 3 shows the effluent color difference from various washings of the stage of cotton pulping.

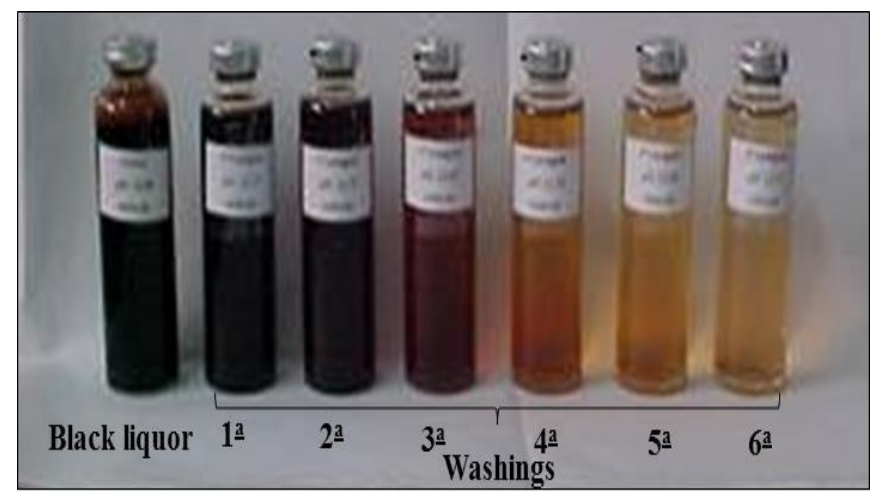

Fig 3-Effluent samples from the stage of cotton pulping, with emphasis on the color difference of washing water effluents [5]

The effluents characterization from the washing waters mixture (pulping effluent) showed that the analyzed parameters, except for $\mathrm{pH}$, are higher than those of the $2^{\text {nd }}$, $3^{\text {rd }}, 4^{\text {th }}, 5^{\text {th }}$ and $6^{\text {th }}$ washings. However, they are much lower than those of black liquor, thus revealing the need for treatment before releasing them into the environment.
By comparing the effluent from the second column (black liquor) to that of the last column of Table 1 (pulping effluent), it was observed that dilution by means of washing waters, which is inherent in the process, has promoted a reduction of color by $77 \%$, COD by $74 \%$, BOD by $77 \%$, SST by $72 \%$, TFS by $73 \%$, TVS by $72 \%$ and nitrogen by $62 \%$. However, the pulping effluent still presents high $\mathrm{pH}$ levels (12.4), color $(28,530 \mathrm{CU}), \mathrm{COD}(7,797 \mathrm{mg} / \mathrm{L})$ and BOD $(4,389 \mathrm{mg} / \mathrm{L})$, which are extremely harmful to the environment, thus highlighting the need to implement a treatment system that reduces these values to acceptable limits.

Thus, the pulping effluent was submitted to the chemical treatment and then to the activated sludge biological treatment. By drawing a comparison of the raw effluent, the chemical process integration followed by the activated sludge biological treatment allowed reducing color by $95.8 \%$, COD by $96.4 \%$, BOD by $99 \%$, TOC by $97.8 \%$, SST by $96.9 \%$, TFS by $95.8 \%$ and TVS by $97.8 \%$, which shows that the integrated process is highly promising for the pulping effluent treatment.

During the biological treatment, there was no significant color change, which may be due to the low removal rate of low molar mass compounds and the formation of new chromophore groups during the biological treatment $[18,19]$, whose process integration results are presented in Table 2. 
Table 2 - Characterization results of the pulping effluent: after chemical and biological treatments with activated sludge [5]

\begin{tabular}{|l|l|l|l|}
\hline \multirow{2}{*}{ Parameters } & \multirow{2}{*}{ Pulping effluent } & After treatment & Biological \\
\cline { 3 - 4 } & & Chemical & 7.6 \\
\hline $\mathrm{pH}$ & 12.4 & 1.5 & 1,207 \\
\hline Color $[\mathrm{CU}]$ & 28,530 & 1,159 & 280 \\
\hline COD $[\mathrm{mg} / \mathrm{L}]$ & 7,797 & 914 & 33 \\
\hline BOD $[\mathrm{mg} / \mathrm{L}]$ & 4,389 & 359 & 54 \\
\hline TOC $[\mathrm{mg} / \mathrm{L}]$ & 2,455 & 153 & 283 \\
\hline TSS $[\mathrm{mg} / \mathrm{L}]$ & 9,269 & 3,541 & 170 \\
\hline TFS $[\mathrm{mg} / \mathrm{L}]$ & 4,035 & 1,464 & 113 \\
\hline TVS $[\mathrm{mg} / \mathrm{L}]$ & 5,234 & 2,077 & 5,3 \\
\hline Nitrogen $[\mathrm{mg} / \mathrm{L}]$ & 27 & 1,6 & $<5$ \\
\hline Phosphorus $[\mathrm{mg} / \mathrm{L}]$ & $<5$ & $<5$ & \\
\hline
\end{tabular}

\section{CONCLUSION}

The chemical treatment made it possible to reduce a large amount of contaminants, which was mainly due to a reduction in color $(96 \%)$, TOC $(94 \%)$, COD $(88.3 \%)$ and BOD $(91.8 \%)$.

Though, in order for the effluent to meet disposal standards, it was necessary to subject it to the activated sludge biological treatment, i.e. to complement the chemical treatment with a biological treatment, which made it possible to further reduce the analyzed parameters values, except for color that had a small increase (4.1\%).

However, the integrated treatment made it possible to reduce COD by $96.4 \%$, BOD by $99 \%$, TOC by $97.8 \%$, SST by $96.9 \%$, TFS by $95.8 \%$ and TVS by $97.8 \%$. These results indicated that the integrated treatment is adequate to treat the cotton pulping effluent for nitrocellulose production.

The variety and frequency of microorganisms observed during the biological monitoring were consistent with the operations of the activated sludge system, being similar to those found in the treatment of domestic sewage.

\section{ACKNOWLEDGEMENT}

The authors thanks the Engineering School of Lorena, University of São Paulo (USP) for the financial this publication.

\section{REFERENCES}

[1]. WANG, Q.; YANG, Z. Industrial water pollution, water environment treatment, and health risks in China 2016. Environmental Pollution (2016), Available in http://dx.doi.org/10.1016/j.envpol.2016.07.011. Access in 28/08/2016

[2]. PAIVA, T.C.B. et al. Characterization of the pulp and bleaching effluents from a nitrocellulose industry and their environmental impact. In: 11 ISWPC, International symposium on wood and pulping chemistry. June, 2001. France. p. $11-14$.
[3]. MACKENZIE, L.D.; DAVID, A.C. Introduction to Environmental Engineering. 2 ed. McGrow-Hill. N.Y.: p. 645 - 722.1991.

[4]. EL-DIWANI, G.; EL-IBIARI, N.N.; HAWASH, S.I. Treatment of hazardous wastewater contaminated by nitrocellulose.JournalofHazardousMaterials $167 \quad$ (2009) 830-834.

[5]. SANTOS, L.F. Caracterização e tratamento de efluentes da fabricação de nitrocelulose. EEL/USP. Lorena/SP. 102 p. (Tese de Doutorado). 2006

[6]. AMARAL, M. C. S.; ANDRADE, L. H.; LANGE, L. C.; Borges, C. P.,Avaliação da biotratabilidade do efluente de branqueamento de polpa celulósica por processos aeróbios e anaeróbios. Eng. Sanit. Ambient. v.18. n 3. jul/set. p. 253-262. 2013.

[7]. SANTOS, L.F.; PAIVA, T.C.B.; SILVA, F.T. Tratamento de efluentes da fabricação de Nitrocelulose scaleup. XX Congresso Brasileiro de Engenharia Química. Florianópolis/SC. 19 a 22 de outubro, 2014.

[8]. SANT'ANNA, G. L. Jr. Tratamento biológico de efluentes: fundamentos e aplicações. Ed. Interciência. 2 ed. Rio de Janeiro/RJ. 418p. 2013.

[9]. TEIXEIRA, C. P. A. B.; JARDIM, W. F. Processos oxidativos avançados: conceitos teóricos, Caderno Temático 03. LQA/Unicamp.Campinas/SP. 2004.Available in http://lqa.iqm.unicamp.br/cadernos/caderno3.pdf. Access in: 31/03/2014.

[10]. BARRETO, M.R.; SOUZA, J.V.B.; SILVA, E.S.; SILVA, F.T.; PAIVA,T.C.B. Combined photo catalytic and fungal processes for the treatment of nitrocellulose industry wastewater, J. Hazard. Mater. 161 (2009) 1569-1573.

[11]. HAMMER, M.J.; HAMMER JR, M.J. Waste and wastewater technology. 6th. ed. Pearson Prentice Hall. Upper Saddle River, New Jersey. 2008. 553p

[12]. METCALF, L., EDDY, H.P. Wastewater Engineering : Treatment, Disposal and Reuse. 3th. ed.McGrow-Hill. 1991. $1334 \mathrm{p}$.

[13]. VON SPERLING, M. Lodos ativados: Princípios do tratamento biológico de águas residuárias. 1. ed. Belo Horizonte. Departamento Engenharia Sanitária e Ambiental (DESA). 1997. v. 4, 416 p.

[14]. BENTO, A.P.; SEVERINO, P.H.; PHILIPPI, L.S.; REGINATTO, V.; LAPOLLI, F.R. Caracterização da 
microfauna em estações de tratamento de esgotos do tipo lodos ativados: um instrumento de avaliação e controle. EngenhariaSanitária e Ambiental.vol. 10 - n 4.p 329 - 338. out./dez. 2005.

[15]. APHA - AMERICAN PUBLIC HEALTH ASSOCIATION AMERICAN WATER WORKS ASSOCIATION (AWWA), WATER ENVIROMENTAL FEDERATION (WEF), Standard Methods for the Examination of Water and Wastewater. 18 ed. American Public Health Association. Washington. 1992.

[16]. SANTOS, L. F.; SILVA, F.T.; PAIVA, T.C.B. Characterization and treatment of effluents from the manufacturing of nitrocellulose to explosives. XXVIII Interamerican Congress of Chemical Engineering Cuzco Peru.October 10-12, Cuzco-Peru.2016

[17]. CONAMA (CONSELHO NACIONAL DO MEIO AMBIENTE-CONAMA) 430, de 13 de maio de 2011. Dispõe sobre as condições e padrões de lançamento de efluentes e complementa e altera a Resolução no 357, de 17 de março de 2005. 2011

[18].THOMPSON, G., SWAIN, J., FOSTER, C.F., KAY, M. The Treatment of Pulp and Paper Effluent : A Review. Bioresouce Tech. 77: 2001. p. 275 - 286.

[19]. MOUNTEER, A.H. et al. Estudo da remoção biológica da DQO recalcitrante de efluente de branqueamento de polpa kraft de eucalipto. In: 35o Congresso e exposição anual de celulose e papel. São Paulo/SP. 14 a 17 de outubro, 2002.

[20]. FOLKE, J.F.; RENBERG, L.; MCCUBBIN, N. Environmental aspects of ECF vs TCF pulp bleaching. In: Environmental fate and effects of pulp and paper mill effluents, St Lucie Press. Delray Beach. p. 681 - 691. 1996. 